https://jurnal.ugm.ac.id/rubikon

\title{
POSTWAR JAPANESE ADOPTION OF AMERICAN CULTURE IN LYNNE KUTSUKAKE'S THE TRANSLATION OF LOVE: A POSTCOLONIAL APPROACH
}

\author{
Bhakti Satrio Nugroho \\ e-mail: bhakti.landt@gmail.com \\ Muh. Arif Rokhman \\ Universitas Gadjah Mada \\ e-mail: arif.soas@gmail.com
}

\begin{abstract}
This paper discusses postwar Japanese adoption of American culture in a debut novel by Lynne Kutsukake entitled The Translation of Love. This novel is set during the U.S. occupation of Japan after the end of World War II. Postwar Japanese are forced to live under American power, while undergoing an economic, social, and moral crisis (kyodatsu). By using postcolonial perspective under Transnational American Studies, this paper finds the adoption of American culture by postwar Japanese characters in the novel, which come from various social backgrounds, including schoolteachers, schoolchildren, bar girls, and prostitutes. The adoption of American culture includes language (English), Western dating (lifestyle), custom, and fashion. This cultural adoption can be defined as the construction of new Japanese society built under American influence to be more "American-oriented". Moreover, it further implies the devaluation of Japanese culture, the humiliation of postwar Japanese people, and the birth of Japanese cultural dependency toward American culture.
\end{abstract}

Keywords: American culture; postcolonial; postwar Japan; transnational; U.S. occupation

DOI $\quad: 10.22146 /$ rubikon.v6i2.61495

Available at https://jurnal.ugm.ac.id/rubikon/article/view/61495

This work is licensed under a Creative Commons Attribution-ShareAlike 4.0 International License

\section{INTRODUCTION}

After its surrender in August 1945, Empire of Japan was forced to accept U.S Initial Post-Surrender Policy for Japan, which was a legal document, approved by U.S. President Harry Truman (Borton, 1948,
Article information

Received: 23 August, 2019

Revised: 6 September, 2019

Accepted: 20 September, 2019 p. 38). This document initialized U.S. occupation of Japan as part of the Japanese consequence of losing in World War II. As military occupation, U.S. occupation of Japan had two main objectives. First, this occupation was made to eliminate Japan's 
war potential in the future by punishing "those who have deceived and misled the Japanese during the war". Second, this occupation intended to turn postwar Japan from totalitarian, ultranationalist and fascist government into a democratic-style nation by establishing American concepts of the nation such as freedom of speech, of religion, and of thought, as well as respect for the fundamental human rights (Kumano, 2007, p. 36). Therefore, postwar Japan was set to be exclusively supervised under foreign military control, Supreme Commander for the Allied Powers (SCAP).

Due to its influential aspect, U.S. Occupation of Japan becomes a literary theme for Lynne Kutsukake's debut novel, The Translation of Love (2016) which was intentionally written to tell her family story of being Japanese-Canadian during that certain period. Kutsukake states that her family, including her grandparents, was sent to internment camps during World War II. Her grandparents later repatriated to Japan after received racial discrimination and lingering prejudice from both Canadian society and government (CBC Radio, 2016). During this period, Japanese-Canadians were labeled as "enemy aliens" and offered two options by the Canadian government: return to Japan or disperse to the east of the Rocky Mountains.

Lynne Kutsukake's The Translation of Love tells the story of the Japanese girl, Fumi Tanaka who tries to find her sister, Sumiko Tanaka, who works in Ginza, entertainment district of Tokyo, as a bar girl for U.S. servicemen. Fumi is helped by her new seatmate at Minami Nishiki Middle School, Aya Shimamura, a Japanese-Canadian repatriated, and Yoshitaka Matsumoto
(Matt), a Japanese-American soldier, who works as translator and typist for U.S. occupation authority. As a debut novel, this novel received many praises from New York Times and The Globe and Mail journalists for offeringrich insights into an underreported period of Japan's, the United States' and Canada's history (Trilby, 2016) (Nimura, 2016).

Thus, this research aims to elaborate and analyze postwar Japanese adoption of American culture during U.S. occupation of Japan, as depicted in Lynne Kutsukake'sThe Translation of Love by using postcolonial perspective under Transnational American Studies. In conducting an in-depth analysis, this research utilizes Homi Bhabha's mimicry which also closely connected to hybridity and ambivalence. This research only focuses on the cultural aspects such as language, custom, lifestyle (in the form of Western dating) and fashion.

Transnational American Studies emphasizes American influences beyond a geographical border. It is a paradigm within American Studies to critically explore American culture and discuss the role of the United States in changing world order (Fluck et al, 2007, p. 1). As a new school or paradigm in American Studies, this paradigm is able to study an issue or phenomenon outside the United States that has a connection with other foreign culture or even vice versa. It further examines American domination and influence overseas. As Rowe asserts: “'Transnationalism' also refers to American Studies done by international scholars outside the U.S. especially scholarship that emphasizes the influence of the U.S. abroad" (2014, p. 1). In this definition, Transnational American Studies 
has closely related to the study of the concept of Western imperialism in which, in this case, instead of European colonial powers, the United States becomes a central dominant country to dominate and imperialize other countries through its political and economic power.

Meanwhile, in definition, postcolonial studies or postcolonialism is an intellectual approach, which focuses on "the contestation of colonial domination and the legacies of colonialism" (Loomba, 2005, p. 16). This dialectical concept does not only discuss the broad historical facts of decolonization and the determined achievement of sovereignty but it also discuss the realities of nations and peoples emerging into a new imperialistic context of economic and political domination (Young, 2016, p. 57). It concerns on both negative and positive effects of the mixing of peoples and cultures (Young, 2016, p. 69). It is critically used to analyze socio-humanities aspects that are circled around colonization and its polemic legacies. It discusses various issues such as the power and colonial relation, which come from the mixed-ness of society and race.

Mimicry is widely known in postcolonial studies to determine the colonized's respond toward the colonizer. In definition, Bhabha defines:

...colonial mimicry is the desire for a reformed, recognizable Other, as a subject of a difference that is almost the same, butnot quite. Which is to say, that the discourse of mimicry is constructed around an ambivalence; in order to be effective, mimicry must continually produce its slippage, its excess, its difference. (Bhabha, 2004, p. 122)
The disparity between the colonizer and the colonized results in the reformation of the colonized as "recognizable Other" by mimicking and adopting behaviors, attitudes, language and culture of the colonizers. It is a result of the colonized's inferiority complex toward the colonizer which psychologically led them to mimic the colonizer (Gupta, 2013 , p. 2). The process of mimicking the Self by the Other, creates postcolonial hybrid and ambiguity which Bhabha called as hybridity and ambivalence. Both aspects are strongly related to mimicry because it is part of mimicry itself. Hybridity emerges as a negotiation between the Self and the Other involves the process of amalgamation, which results in "the loss of purity" within indigenous culture. In other words, hybridity commonly refers to the creation of new transcultural forms within the contact zone produced by colonization (Ashcroft et al, 2007, p. 108). However, by adopting the colonizer's cultural habits, the result will never be a simple reproduction of those traits (Ashcroft et al, 2007, p. 125). Meanwhile, in definition, ambivalence is defined as "a continual fluctuation between wanting one thing and wanting its opposite" (Young in Ashcroft et al, 2007, p. 10). Theoretically, it is the idea of seeing culture as consisting of opposing perceptions and dimensions. It is also defined as a person who experiences opposing emotions and attitude regarding the colonial changes brought by the colonizer during the colonization.

This research is a qualitative which refers to "the meanings, concepts, definitions, characteristics, metaphors, symbols, and descriptions of things" (Lune \& Berg, 2017, p. 12). In other words, 
qualitative research is descriptive method of analyzing the text, which emphasizes on the researcher's interpretation of meaning toward the issues. Creswell further defines qualitative research as "a means for exploring and understanding the meaning individuals or groups ascribe to a social or human problem" (2009, p. 3). It focuses on the individual meaning and the importance of rendering the complexity of the discussion.

In conducting a qualitative research, it relies on qualitative data, which mean material things which are used by the researcher to investigate (Leedy, 2009, p. 86). Moreover, due to its systematical and academicpurpose,this research needs technique data analysis to classify and to arrange the data based on the research purposes andobjectives (Mahsun, 2005, p. 253), which include (1) data selection, (2) data interpretation, and (3) data conclusion.

\section{DISCUSSION}

\section{Postwar Japanese Adoption of English}

This novel consists of English adoption, which is glorified as the language of the occupying power by postwar Japanese. It is often spoken and learned by postwar Japanese characters that came from various social backgrounds such as schoolchildren, professionals, and prostitutes. For instance, for Kondo, who works as a teacher at Minami Nishiki Middle School and freelance translator at Love Letter Ally (Koibumi Yokocho), English brings social and economic benefits for him. When working as a freelance translator, he sells his service by praising the superiority of English as the language of U.S. soldiers (Kutsukake, 2016, p. 41). In this case, English strengthens his position as a schoolteacher who used to be condemned for his knowledge of the enemy's language (tekikokugo) and it brings more income since, during U.S. occupation, it is considered as high-class language. Meanwhile, many Japanese children brokenly speak English to U.S. soldiers. As U.S. soldiers, Matt and Eddie as U.S. soldier are always targeted for Japanese children to be asked for chocolate and gum (Kutsukake, 2016, pp. 53, 299). At this point, English becomes a tool for these children to gain the occupiers' preferable goods such as sweets, chocolate, gum and even cigarette. Then, at Minami Nishiki Middle School, most of the Japanese schoolchildren can hardly read English and are only able to speak some basic words and phrases (Kutsukake, 2016, p. 19). These rudimentary words and phrases in English become a catchphrase for the approach Japanese children adopted toward the conquerors (Dower, 2000, p. 72). It becomes part of postwar Japanese children's play during U.S. occupation. In other words, it is a simple gesture but it has broader meaning since it implies the dependency of these young Japanese toward U.S. soldiers.

For Japanese professionals and schoolchildren, the English adoption by postwar Japanese represents various implications regarding Japan's position after the war. Previously, during prewar and wartime period, English was rarely learned and spoken due to nationalist sentiments such as "education in Japan in Japanese" policy (Butler, 2007, p. 131) anti-patriotic sentiments such as tekikokugo (enemy's language) policy (Johnston, 2015). It means that the English adoption by postwar Japanese schoolchildren implicates the successful attempt of the United States in conquering Japan, in almost every aspect of their cultural and social life. Meanwhile, for 
postwar Japanese women who either work as panpan girls or seek romantic liaison with U.S. soldiers, English is one of the most important American aspects to be imitated. For instance, when U.S. soldiers, Matt and Eddie decide to go to an entertainment district in Ginza, they meet a Japanese woman, who addresses them in basic and seductive English greeting "Come on, honey" (Kutsukake, 2016, p. 139). The woman who greets Matt and Eddie in English is either a bar girl or panpan girl work in Ginza, the entertainment district of Tokyo. Panpan girls were often described as "women of the night" or "streetwalkers" who could be easily identified with their red lipstick, nail polish, cigarettes, high heels, strong perfume, and provocative dress codes. At this point, the interaction between U.S. soldiers and panpan girls creates a pidgin called "Panlish" which is a colloquial English spoken by panpan girls (Sakamoto, 2010, p. 5). This Japanese pidgin, panlish is one of the results of this new transcultural forms which created by the negotiation between U.S. soldiers and postwar Japanese.

In a postcolonial context, language adoption of the colonizer's language by the inferior colonized is mimicry. In this notion, the colonizer, in this case, U.S. occupation authority, wants to improve and make the Other (postwar Japanese) to look like themselves, but in a way, it still maintains a clear sense of difference. For postwar Japanese characters who speak English, either from civilians or professionals, the way they speak is fundamentally different with the way U.S. soldiers speak. Due to the vernacular lingual aspects, these postwar Japanese cannot perfectly mimic the colonizer's cultural aspects, especially English that is very hard to be pronounced by most Japanese. Therefore, this lingual deficiency implies the difference between postwar Japanese characters in mimicking their colonizer's language.

Furthermore, mimicking the language of the colonizer is a fundamental transition for accepting the "foreignness" within a native's culture. Shakib explains that language functions as a gateway of cultural identity in which when the colonizer's language is adopted, there will be the adoption of other colonizer's cultural values and products (2011, p. 118). It strengthens the domination and superiority of the colonizer. There is degradation of Japanese pride dealing with their national purity which used to refuse to accept the claim of otherness by the West.

\section{Postwar Japanese Adoption of Western Dating}

Another adoption is Western dating (abekku), which shows the fraternization or social engagement between U.S. soldiers and postwar Japanese women, especially bar girl, panpan girl and "only" (a panpan girl who was loyal to a single American patron). For instance, during his visit in Hibiya Park, Matt encounters many Japanese from various social backgrounds, who enjoy this large public space, including U.S. soldiers with their Japanese spouses and Japanese men with their Japanese women, "The Japanese couples walked shyly side by side, never touching, but the G.I.s always held hands with their Japanese girlfriends" (Kutsukake, 2016, p. 52). Postwar Japanese couples, as represented by those Japanese couples in Hibiya Park, start adopting "free relations 
between men and women" (jiyu' nadanjokosai) introduced by U.S. soldiers which manifested into abekku (means "Westernstyle" dating couple) (McLelland, 2012, p. 124).

As it is explained in the previous discussion, American dating is not actually in line with Japanese cultural value in which it requires women to be submissive toward men. Thus, it is considered as a process of cultural adoption that shows the significant impacts of U.S. occupation in postwar Japan.At this point, a male and female social relationship (danjoko-sai) tends to shift from Confucian-style into American-style, which emphasizes on personal freedom. American lifestyle becomes a correct model of the society, which should be followed by postwar Japanese in order to reform themselves as recognizable Other.

As a result, postwar Japanese began to free themselves from traditional norms and cultural value that exist as part of Japanese cultural characteristics. In a broader perspective, young adults are adaptive toward social changes since they acquire autonomy and building a sense of self (Benson \& Elder, 2011, p. 1646). It is an age of identity construction, which is eager and willing to fuse their identity with others (Erikson, 1977, p. 237). Therefore, the cultural adoption of Western dating (abekku) which mostly conducted by postwar Japanese young adults resembles the significance of American cultural imposition regarding dating and free relation between men women in postwar Japanese society.

\section{Postwar Japanese Adoption of American Custom}

The third adoption is American customs which such as chewing gum and bread-based diet custom. For instance, many postwar Japanese children do not feel remorse to follow and copy U.S. soldiers' behavior with their panpan women (Kutsukake, 2016, p. 23). Like a smoking cigarette, U.S. soldiers' custom becomes a new attraction that easily copied by most of postwar Japanese. In this context, postwar Japanese, including these little boys and panpan women, blindly follow U.S. soldiers without even look at its consequences.In this story, during Fumi's quest to find her sister in Ginza, she meets Hisayo, a teenager who works as either bar girl or panpan girl. She invites Fumi to stay in her dorm and reveals that she rapidly follows the culture which is brought by U.S. soldiers (Kutsukake, 2016, p. 246). It shows Hisayo's lack of knowledge about gum since this foreign product is originally invented in the United States. This iconic and popular symbol of "American invention" in 1930s and 1940s represents American industrialization prosperity during and after World War II (Redclift, 2002, p. 396). Since during U.S. occupation American culture becomes "correct model" of the society, postwar Japanese blindly adopt it due to their admiration toward U.S. soldiers.

Meanwhile, like chewing gum custom, the presence of U.S. soldiers during the occupation, changes postwar Japanese custom on a diet. As part of humanitarian aid, American food began to be imposed to postwar Japan, especially in Japanese schools, including Minami Nishiki Middle (Kutsukake, 2016, pp. 20-21). This policy unconsciously switches postwar Japanese diet rice-based custom from their traditional food to American food which mostly wheatbased. This consumption of American diet 
custom can be defined as cultural adoption since the dissemination of this custom eliminates the element of nativeness and simultaneously endorses the foreignness of the colonizer's culture.

American food represents the process of Americanization of postwar Japan in the direction of American capitalist power. Dower says, the consumption of bread and other wheat-based food imposed by U.S. occupation authority is not only a matter of survival but it is "a small manifestation of the horizontal Westernization that reached into every corner of society" (Dower, 2000, p. 170). It means that the United States as the new rulers of postwar Japan, manages to penetrate every aspect of Japanese life. In other words, postwar Japanese society becomes a mere colonial subject in which they are able to bring a benefit for the United States. Thus, by adopting this custom, postwar Japan had felt into the American capitalist web.

Furthermore, although most of postwar Japanese began to consume American food and adopt wheat-based diet custom, they also still depend on rice as a staple. It means that they cannot entirely negate their preoccupation tradition, which is still firmly embedded as custom and cultural value. It is seen as a sense of difference in the process of mimicking the Self, which implicates the colonized's ambivalence. It is a manifestation of the colonized's cultural disorientation on their own soil due to the arrival of foreigners as occupying power. This adoption of American custom is mimicry. However, they cannot fully mimic what U.S. soldiers already impose to them due to their nativeness, which is already embedded in their daily life. It symbolizes the superiority of U.S. occupation authority in changing postwar Japanese in the direction of its capitalist power. Their inferiority during the occupation results in cultural dependency, which considers the United States as the source of modern and correct culture.

\section{Postwar Japanese Adoption of American Fashion}

The last adoption is American fashion which is adopted mostly by postwar Japanese women who work closely with U.S. soldiers such as bar girls and panpan girls. They undergo a major cultural transformation in the form of American fashion adoption. They began to adopt American fashion, which includes the use of Western clothing (yofuku), haircut and make-up to signify their adaptive behavior toward social change brought by U.S. occupation authority. It further becomes an obsession that is part of a new cultural identity for postwar Japanese women. For instance, during her encounter with Fumi and Aya, Hisayo, a teenager who works as a bar girl, explains and expresses her admiration toward American clothing (Kutsukake, 2016, p. 235). By looking at this conversation between Hisayo and Fumi, it reveals that Hisayo is obsessed with American goods in which she adores it as part of her cultural orientation.

In this case, she refers American nightgown as "what a real woman wears" which means that it shows her obsession and admiration as the colonized or the Other toward the occupying powers, the United States and its culture. She considers American woman as a "true woman" that 
should be followed since during the occupation U.S occupation authority sets up "a glamorous white American" as a role model and ideal beauty for postwar Japanese women and girls to emulate (McAndrew, 2011, p. 85). In other words, she is unconsciously othering herself and her culture, Japanese culture in which she accepts "the otherness" stereotype by U.S. occupation authority, which propagates American society as a correct model of civilization. Therefore, postwar Japanese have to follow their occupier's culture if they want to be recognized as part of their occupier's civilization.

Moreover, when Hisayo meets Aya who wears American coat from Canada, she expresses her interest to wear it even though it does not even fit on her body, "What a beautiful coat. It's so soft and warm. I've always wanted a real American coat" (Kutsukake, 2016, p. 357). Hisayo shows her obsession toward American fashion, specifically American clothing which, at the time, mostly popularized by Hollywood film and fashion industry. In this case, Hisayo's admiration toward American coat represents the obsession of postwar Japanese women, specifically young panpan girls to dress in American-style of fashion in which she wants to be "a modern and stylish woman".

Furthermore, this adoption also gives a sense of power. For Sumiko, she adopts American or Western clothing (yofuku) after she gains a job as a bar girl in Mr. Harada's dance club, which is specifically intended for American guests. In this case, by dressing like American women such as wearing sharp female clothes, high-heeled shoes combine with wavy hair, and heavy make-up, she feels powerful, wanted, and superior as a woman
(Kutsukake, 2016, p. 114) since most of postwar Japanese begin to notice her stylish and modern style of cultural identity in the middle of the newly constructed society. It is a form of colonial obsession, which shifts their cultural orientation into the colonizer's direction. It further becomes the pride for bar girls and panpan girls to dress in Western or American clothing (yofuku) because American-style fashion later defines the status of these Japanese women during U.S. occupation.

Despite receiving negative stigma and social criticism from elder generation within postwar Japanese society, dressing as American woman becomes very common behavior for young Japanese women. In this case, as Sumiko tells her mother that, American fashion becomes a utopian dream for many postwar Japanese women in which some of them cannot afford to buy it (Kutsukake, 2016, p. 77). Due to their stylish and modern elements, American clothes become an attraction and the desired object to be adopted by young Japanese women. For the elder Japanese generation, adopting American fashion would result in negative stigma and social criticism since this type of fashion is associated with prostitution. However, many of these postwar Japanese female characters are not aware of this social criticism since it becomes a utopian product to be consumed. Thus, adopting American fashion is the reflection of a new young Japanese society that does not want to be tied by traditional norms.

For some young Japanese women, dressing as American women resembles a form of "American Dream". As what happens to Yoko and Hisayo, by dressing as American women, they want to be 
recognized by the new constructed Japanese society and hope to have a romantic liaison with U.S. soldiers. This "American Dream" later constructs the way postwar Japanese women think about their own culture and American culture. As a result, there is a shift of cultural preference among young Japanese women which devaluates Japanese culture under "the stylish and modern" of American culture.

On the other hand, by adopting American fashion, these young Japanese women, including Sumiko, are not able to fully transform themselves into "White women". The elements of nativeness, which physically and culturally attached to them, prevent them to do so. For instance, during his visit to one of the dance clubs in Ginza, Matt describes that, American fashion, which basically Caucasian-oriented, is not suitable with most of Japanese women since they are Asian (Mongoloid) (Kutsukake, 2016, p. 138). Despite Japanese bar girls' glamorous clothes and red-lipstick, there is a sense of difference based on racial appearance, which cannot be manipulated with make-up and other American fashion products.

In other words, while mimicking white American woman, who is regarded as a "true woman", they cannot erase a racial difference that physically differentiates between Caucasian women (American) and Mongoloid (Japanese). Therefore, the American or Hollywood ideal beauty, which is implicitly propagated and disseminated through Japanese media during the occupation, cannot be fully achieved by these young Japanese women such as Sumiko, Hisayo and Yoko, due to these racial and cultural differences. This colonial adoption only results in "blurred copy" of an American woman.

By adopting American fashion, there is a process of amalgamation, which signifies "the loss of purity" within Japanese culture. This "blurred copy" of the colonizer is regarded as hybridity since it consists of the mixed-ness between the nativeness and foreignness which results in cultural impurity. It emerges when there is a contact of interaction and negotiation between the Self (the colonizer) and the Other (the colonized) which produces the creation of new transcultural forms (Huddart, 2006, p. 4) (Ashcroft et al, 2007, p. 108). American fashion can be translated as a product of cultural convergence, which combines the inferior Japanese culture and the superior American culture. However, in a broader perspective, the adoption of American fashion resembles the fall of postwar Japanese society into American consumerism culture under its capitalist system. It becomes an irony since, during prewar and wartime, Empire of Japan used to be proud of its own commodities and condemned American capitalism and imperialism under the spirit of Pan-Asianism which emphasizes on "antiWest" and "anti-Western domination". Thus, the adoption and consumption of American fashion products symbolize the humiliation of defeated Japan under American power.

\section{CONCLUSION}

In conclusion, in Lynne Kutsukake'sThe Translation of Love, the adoption of American cultures such as language, lifestyle, custom and fashion, asserts that the democratization of the defeated Japan results 
in the social and cultural changes within the core of Japanese civilization. This cultural adoption can be defined as the construction of new Japanese society, which is built under American power. It also shows the significance of Americanization of postwar Japan which is transformed by the United States from the ultranationalist nation into "American-oriented" nation. Therefore, postwar Japanese culture begins to accept Western culture as part of its new cultural orientation and preference. This acceptance and further adoption not only result in the devaluation of Japanese culture and the humiliation of postwar Japanese people, but it also causes a cultural dependency toward American culture. Thus, democratization becomes an influential attempt for the United States to culturally exploit postwar Japanese society. However, due to the racial and cultural attachments, the result of this cultural adoption is only a "reproduction". Instead, it is a form of mockery which embodies an exaggeration of adopting American culture as the occupying power's culture.

\section{REFERENCES}

Ashcroft, B., Griffiths, G., \& Tiffin, H. (2007). Post-Colonial Studies: The Key Concepts. New York: Routledge.

Benson, J., \& Elder, G. (2011). Young Adult Identities and Their Pathways: A Developmental and Life Course Model. DevPsychol, 47(6), 1646-1657.

Bhabha, H. (2004). The Location of Culture. London and New York: Routledge.

Borton, H. (1948). American Occupation Policies in Japan. Proceedings of the Academy of Political Science, 22(4), 37-45.
Butler, Y. (2007). Foreign Language Education at Elementary Schools in Japan: Searching For Solutions amidst Growing Diversification. Asia-Pacific Education, Language Minorities and Migration (ELMM) Network Working Paper Series, 3, 129-147.

CBC Radio. (2016). Why Lynne Kutsukake Wrote The Translation of Love. Retrieved December 2, 2019, from https://www.cbc.ca/radio/thenextchapte r/teva-harrison-on-cancer-michaelcoren-on-gay-marriage1.3581810/why-lynne-kutsukakewrote-the-translation-of-love1.3581837

Creswell, J. (2009). Research Design: Qualitative, Quantitative, and Mixed Methods Approaches. Los Angeles: SAGE Publication.

Dower, J. (1993). Embracing Defeat: Japan in the Wake of World War II. New York: WW Norton \& Company.

Erikson, E. (1977). Childhood and Society. London: Paladin Grafton Books.

Fluck, W., Brandt, S., \& Thaler, I. (2007). Introduction: The Challenges of Transnational American Studies. REAL - Yearbook of Research in English and American Literature, 23, 1-7.

Gupta, A. (2013). The Role of "Mimicry" in Colonial and Post-colonial Discourse with special reference to Homi Bhabha's of Mimicry and Man: The Ambivalence of Colonial Discourse. IRWLE, 9(2), 1-6.

Huddart, D. (2006). Homi K. Bhabha. New York: Routledge.

Johnston, E. (2015). Truth Hurts: Censorship in the Media. Retrieved December 5, 
2019 ,

from

https://www.japantimes.co.jp/news/201

5/08/08/national/history/truth-hurtscensorship-media/\#.XeuLwRsxX6Q

Kumano, R. (2007). The U.S. Occupation and Japan's New Democracy. Educational Perspectives, 40(1), 36-4.

Kutsukake, L. (2016). The Translation of Love. New York: Penguin Random House.

Leedy, P. (1985). Practical Research. New York: Macmillan Publishing Company.

Loomba, A. (2005). Colonialism/ Postcolonialism. New York: Taylor \& Francis Group.

Lune, H., \& Berg, B. (2017). Qualitative Research Methods for the Social Sciences. Malaysia: Pearson Education Limited.

Mahsun. M. (2005). Metode Penelitian Bahasa: Tahapan Strategi, Metode, dan Tekniknya. Jakarta: PT. Raja Grafindo Persada.

McAndrew, M. (2014). Beauty, Soft Power, and the Politics of Womanhood during the U.S. Occupation of Japan, 19451952. Journal of Women's History, 26 (4), 83-107.

McLelland, M. (2012). Love, Sex, and Democracy in Japan during the American Occupation. New York: Palgrave Macmillan.

Redclift, M. (2002). Chewing Gum in the United States and Mexico: the Everyday and the Iconic. Sociologia Ruralis, 42 (4), 391-403.

Rowe, J. (2014). Featured Articles: Three Articles on Transnationalism and
American Studies. American Studies Association. Retrieved July 15, 2014, from

http://www.theasa.net/project_eas_onli ne/page/project_eas_online_eas_featur ed_article/

Sakamoto, R. (2010). Pan-Pan Girls: Humiliating Liberation in Postwar Japanese Literature. PORTAL, 7(2), 115.

Shakib, M. (2011). The Position of Language in Development of Colonization. Journal of Languages and Culture, 2(7), 117-123.

Trilby, K. (2016). Review: Lynne Kutsukake's The Translation of Love Offers Rich Insights into an Underreported Period. Retrieved October 18, 2019, from https://www.theglobeandmail.com/arts/ books-and-media/bookreviews/review-lynne-kutsukakes-thetranslation-of-love-offers-rich-insightsinto-an-underreported-period-inhistory/article29569056/

Young, R. (2016). Postcolonialism: An Historical Introduction. Oxford: John Wiley \& Sons, Ltd. 